Published in final edited form as:

J Am Chem Soc. 2018 December 12; 140(49): 17153-17162. doi:10.1021/jacs.8b09914.

\title{
Substrate Binding Regulates Redox Signaling in Human DNA Primase
}

\author{
Elizabeth O’Brien ${ }^{\dagger, \ddagger}$, Marilyn E. Holt ${ }^{\S}$, Lauren E. Salay ${ }^{\S}$, Walter J. Chazin ${ }^{\star}, \S$, and Jacqueline \\ K. Barton ${ }^{*}, \dagger$ \\ †Division of Chemistry and Chemical Engineering, California Institute of Technology, Pasadena, \\ California 91125, United States \\ §Departments of Biochemistry and Chemistry, Center for Structural Biology, Vanderbilt University, \\ Nashville, Tennessee 37240, United States
}

\section{Abstract}

Generation of daughter strands during DNA replication requires the action of DNA primase to synthesize an initial short RNA primer on the single-stranded DNA template. Primase is a heterodimeric enzyme containing two domains whose activity must be coordinated during primer synthesis: an RNA polymerase domain in the small subunit (p48) and a [4Fe4S] cluster-containing C-terminal domain of the large subunit (p58C). Here we examine the redox switching properties of the [4Fe4S] cluster in the full p48/p58 heterodimer using DNA electrochemistry. Unlike with isolated $\mathrm{p} 58 \mathrm{C}$, robust redox signaling in the primase heterodimer requires binding of both DNA and NTPs; NTP binding shifts the p48/p58 cluster redox potential into the physiological range, generating a signal near $160 \mathrm{mV}$ vs NHE. Preloading of primase with NTPs enhances catalytic activity on primed DNA, suggesting that primase configurations promoting activity are more highly populated in the NTP-bound protein. We propose that p48/p58 binding of anionic DNA and NTPs affects the redox properties of the [4Fe $4 \mathrm{~S}]$ cluster; this electrostatic change is likely influenced by the alignment of primase subunits during activity because the configuration affects the [4Fe4S] cluster environment and coupling to DNA bases for redox signaling. Thus, both binding of polyanionic substrates and configurational dynamics appear to influence [4Fe4S] redox signaling properties. These results suggest that these factors should be considered generally in characterizing signaling networks of large, multisubunit DNA-processing [4Fe4S] enzymes.

\section{Graphical Abstract}

${ }^{*}$ Corresponding Authors: jkbarton@caltech.edu, walter.j.chazin@vanderbilt.edu.

†Present Address: Department of Chemistry, University of California, Berkeley, Berkeley, CA 94720

The authors declare no competing financial interest.

Supporting Information

The Supporting Information is available free of charge on the ACS Publications website at DOI: 10.1021/jacs.8b09914.

Electrochemistry of electrochemically unaltered wild-type p48/p58, UV-visible spectra of wild-type and mutant p48/p58, additional biochemistry experiments assessing the role of substrate binding order on primase initiation, an electrostatic map of the primase/p58C DNA binding interface, and a table of DNA substrates used in the experiments (PDF) 


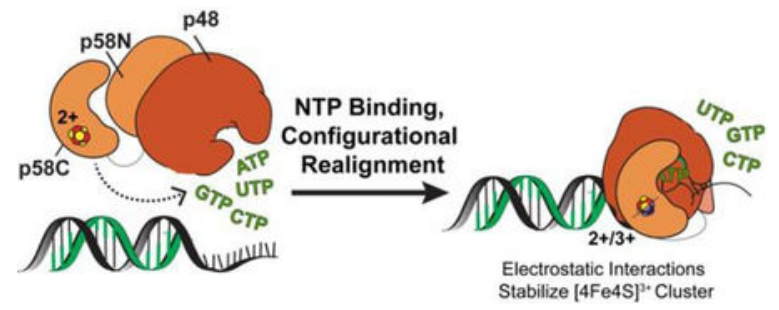

\section{INTRODUCTION}

Dynamic, coordinated DNA replication in eukaryotic cells must efficiently duplicate genomes on the scale of $10^{6}-10^{9}$ base pairs with error rates of approximately $10^{-9}$ mismatches per replication cycle. ${ }^{1}$ The enzyme responsible for initiating daughter strand synthesis in eukaryotes is a heterodimeric DNA-dependent RNA polymerase, DNA primase. 2-6 Primase is a heterodimer containing an RNA polymerase subunit, $\mathrm{p} 48$, and a regulatory subunit, p58. ${ }^{7-10}$ Primase exists in complex with the heterodimeric DNA polymerase $a$ (polprim), which functions to generate the RNA-DNA primer required for the bulk of genome duplication by processive DNA polymerases $\varepsilon$ and $\delta .{ }^{3-6,11-13}$ Primase binds the ssDNA template, along with two nucleotide triphosphates (NTPs) and two catalytic metals, to synthesize the first dinucleotide (nt). After dinucleotide synthesis, primase rapidly elongates the primer to appropriate length (8-14 nts), before handing the primer off to polymerase $a$. Polymerase $a$ then adds 10-20 deoxynucleotide triphosphates (dNTPs) downstream of the initial RNA primer before handing off the substrate to one of the processive DNA polymerases to complete genome duplication.

All eukaryotic replicative polymerases, as well as the translesion synthesis B-family polymerase $\zeta{ }^{14-16}$ are reported to contain [4Fe4S] clusters, which are metabolically expensive cofactors associated with biological redox chemistry. ${ }^{17,18}$ The clusters in both DNA polymerase $\delta^{19}$ and the [4Fe4S] domain of primase, p58C, ${ }^{20}$ can be oxidized and reduced when bound to DNA through DNA-mediated charge transport (DNA CT). DNA CT is a long-range, rapid, and mismatch-sensitive biochemical process, ${ }^{21-23}$ making it interesting to consider as a regulatory mechanism for replication. Moreover, experiments support the application of this chemistry in locating oxidative lesions in vitro and in cells ${ }^{24-26}$ by DNA repair enzymes containing [4Fe4S] clusters.

The $\mathrm{p} 58 \mathrm{C}$ domain of human and yeast DNA primase has been demonstrated electrochemically to undergo DNA-mediated redox switching between an oxidized, $[4 \mathrm{Fe} 4 \mathrm{~S}]^{3+}$ state and a resting, $[4 \mathrm{Fe} 4 \mathrm{~S}]^{2+}$ redox state. ${ }^{20,27}$ The oxidized $[4 \mathrm{Fe} 4 \mathrm{~S}]^{3+} \mathrm{p} 58 \mathrm{C}$ is tightly bound to DNA, whereas the reduced $[4 \mathrm{Fe} 4 \mathrm{~S}]^{2+} \mathrm{p} 58 \mathrm{C}$ is only loosely bound to DNA. A similar switch is evident in the base excision repair protein, Endonuclease III, which contains a $\left[4 \mathrm{Fe} 4 \mathrm{~S}\right.$ ] cluster; here binding to the DNA polyanion shifts the $[4 \mathrm{Fe} 4 \mathrm{~S}]^{3+/ 2+}$ redox potential so that the oxidized $[4 \mathrm{Fe} 4 \mathrm{~S}]^{3+}$ form binds DNA 500 -fold more tightly than the $[4 \mathrm{Fe} 4 \mathrm{~S}]^{2+}$ form..$^{28,29}$ This redox switch in $\mathrm{p} 58 \mathrm{C}$ appears to regulate primase activity and primer product distribution, yet the electrochemical behavior of the full primase enzyme, relative to that of p58C, has yet to be reported. Since both the catalytic subunit (p48) and the regulatory subunit containing the $[4 \mathrm{Fe} 4 \mathrm{~S}]$ cluster (p58) of primase are required for binding 
of DNA and NTPs to initiate primer synthesis, ${ }^{7-10,30,31}$ the electrochemical behavior of the complete $\mathrm{p} 48 / \mathrm{p} 58$ heterodimer is likely an important element of the mechanism driving primer synthesis.

The $\mathrm{p} 48$ and $\mathrm{p} 58 \mathrm{C}$ domains must be positioned near one another during priming, so that both can contact the template DNA; however, the DNA binding interfaces of $\mathrm{p} 48$ and $\mathrm{p} 58 \mathrm{C}$ are separated by approximately $60 \AA$ in the crystal structure of free primase. ${ }^{7}$ These structural data suggest that primase must undergo a significant configurational rearrangement when binding DNA and NTPs, specifically a subunit realignment to position $\mathrm{p} 58 \mathrm{C}$ over the $\mathrm{p} 48$ active site to begin primer synthesis. Beyond configurational rearrangement, moreover, the electrostatic environment of the [4Fe4S] cluster cofactor in primase is likely changed dramatically by the binding of the anionic DNA and NTP substrates, as it is for Endonuclease III. Because electrostatic environment is a major factor in shifting the redox potential of [4Fe4S] cluster cofactors, ${ }^{32}$ it is reasonable to consider that binding of DNA and NTPs may change the redox behavior of the full-length $\mathrm{p} 48 / \mathrm{p} 58$ primase enzyme. Characterization of both the electrostatic effect of DNA and NTP binding on primase $[4 \mathrm{Fe} 4 \mathrm{~S}]$ cluster redox behavior and the configurational rearrangement of primase upon substrate binding, which positions the RNA polymerase and [4Fe4S] domains near the DNA, close to one another, is crucial for understanding the biochemical factors coordinating primase activity, which eventually culminates with primer termination and handoff to polymerase $a$.

Here we use DNA electrochemistry to investigate the electrostatic effects of DNA/NTP binding on primase redox activity. We find that full-length human primase displays a small amount of redox signaling upon electrochemical oxidation in the presence of DNA, though oxidation in the presence of DNA alone is a more dramatic redox switch for the isolated p58C domain. ${ }^{20}$ When bound to both DNA and NTPs, however, p48/p58 displays robust, semireversible redox activity. Binding of anionic substrates changes the electrostatic environment of the primase [4Fe $4 \mathrm{~S}$ ] cluster, shifting the potential into signaling range with other [4Fe4S] enzymes. Moreover, alignment of p58C over the active site of p48 should also alter the electrostatic field of the cluster. Preloading p48/p58 with NTPs, additionally, enhances catalytic activity on an exogenously primed substrate. In addition to the shift in electrostatic environment of the cluster, preloading NTPs should promote formation of the active primase initiation complex, with $\mathrm{p} 58 \mathrm{C}$ and $\mathrm{p} 48$ proximal to the DNA template and NTPs bound in both the $3^{\prime}$ and $5^{\prime}$ sites.

Thus, the redox switch driven by the primase [4Fe4S] cluster is activated upon DNA and NTP binding, and combined with changes in configuration, regulates multistep RNA synthesis.

\section{MATERIALS AND METHODS}

\section{Protein Expression and Purification.}

Full-length primase was expressed and purified as described previously. ${ }^{33}$ In short, plasmid DNA was transformed into BL21RIL (DE3) cells (Novagen), and cultured at $37{ }^{\circ} \mathrm{C}$ to an $\mathrm{OD}_{600}$ of 0.6 , when flasks were transferred to an $18^{\circ} \mathrm{C}$ incubator with shaking. After 30 
min, protein expression was induced through addition of isopropyl 1-thio- $\beta$-Dgalactopyranoside to a final concentration of $5 \mathrm{mM}$. Media was also supplemented at this time with ferric citrate and ammonium ferrous citrate to a final concentration of $0.1 \mathrm{mg} / \mathrm{mL}$. The primase subunits were expressed at $18{ }^{\circ} \mathrm{C}$ for $18 \mathrm{~h}$ prior to harvesting and freezing at $-80^{\circ} \mathrm{C}$. After lysis, primase was first purified by nickel affinity chromatography (Amersham Biosciences). The $6 \mathrm{xHis}$ tag on $\mathrm{p} 48$ was the cleaved with $\mathrm{H} 3 \mathrm{C}$ protease and primase dialyzed into a low-imidazole buffer. ${ }^{33}$ Primase was then repassed over the nickel column to remove the $\mathrm{H} 3 \mathrm{C}$ protease and uncleaved protein. A heparin column was used to remove residual contaminants before passing over a Sephadex S200 sizing column to remove aggregates and buffer exchanged into electrochemistry storage buffer: $20 \mathrm{mM}$ TRIS, pH 7.2, $150 \mathrm{mM} \mathrm{NaCl}, 5 \%$ glycerol. $^{33}$

\section{Oligonucleotide Preparation.}

All standard or modified phosphoramidites and DNA synthesis reagents were purchased from Glen Research. Unmodified DNA oligonucleotides for electro-chemical experiments were purchased from Integrated DNA Technologies, Inc. Thiol-modified DNA strands for electrochemistry were made on an Applied Biosystems 3400 DNA synthesizer, with a C6 S -S phosphoramidite incorporated at the $5^{\prime}$-terminus. Single-stranded DNA was purified using standard procedures as described previously. ${ }^{34,35}$ High pressure liquid chromatography (HPLC) using a reverse-phase PLRP-S column (Agilent) was used, and oligonucleo-tide mass confirmed using MALDI-TOF mass spectrometry. Thiolmodified strands were reduced after the initial HPLC purification with $100 \mathrm{mM}$ dithiothreitol (Sigma) for $2-3 \mathrm{~h}$ in $50 \mathrm{mM}$ Tris-HCl, $\mathrm{pH} 8.4,50 \mathrm{mM} \mathrm{NaCl}$. Reduced thiol-modified DNA was purified by size exclusion chromatography (Nap5 Sephadex G-25, GE Healthcare) and subsequent reverse-phase HPLC. Single-stranded oligonucleo-tides were then desalted using ethanol precipitation and stored in low salt buffer (5 mM Phosphate, $\mathrm{pH} 7.0,50 \mathrm{mM} \mathrm{NaCl})$. Duplex DNA for electrochemistry was prepared by quantification of the complementary single-stranded oligonucleotides by UV-visible spectroscopy, followed by annealing at $90{ }^{\circ} \mathrm{C}$. A mixture of equimolar complementary single-stranded DNA $(50 \mu \mathrm{M})$ was prepared in low salt buffer. Thiol-modified duplex DNA substrates were then deoxygenated by bubbling argon gas through the solution for 90-180 s. Duplex DNA was annealed on a thermocycler (Beckman Instruments) by initial heating to $90{ }^{\circ} \mathrm{C}$, followed by slow cooling to $4{ }^{\circ} \mathrm{C}$ over $90 \mathrm{~min}$. DNA was quantified using absorbance at $260 \mathrm{~nm}$, with extinction coefficients at $260 \mathrm{~nm}$ for DNA obtained using Integrated DNA Technologies online OligoAnalyzer tool. Single-stranded DNA substrates were quantified using UV-visible spectroscopy and stored in low salt buffer at a stock concentration for activity assays.

\section{Multiplexed Chip Fabrication.}

Multiplexed electrode platforms were prepared using standard photolithography techniques, adapted from established protocols. ${ }^{23,34,35}$ Nine 1 in. by 1 in. chips were patterned on 525 $\mu \mathrm{m}$ thick silicon wafers (SiliconQuest). A thermal oxide layer roughly $4000 \AA$ A thick was grown on the silicon wafers using a Tytan tube furnace (Tystar). $\mathrm{S} 1813$ photoresist $(2 \mu \mathrm{m}$ layer) was deposited onto the wafers for patterning of the chips before metal deposition. Electron beam evaporation (CHA Industries) was then used to deposit a $3 \mathrm{~nm}$ titanium 
adhesion layer followed by a $100 \mathrm{~nm}$ gold layer, without breaking vacuum between depositions.

Metal lift-off using Remover PG (MicroChem) was performed overnight (10-12 h) at ambient temperature. Wafers were subsequently dried with a nitrogen gun and dehydrated at $140{ }^{\circ} \mathrm{C}$ for $10 \mathrm{~min}$. A $3 \mu \mathrm{m}$ layer of insulating SU-8 photoresist was deposited and patterned onto the wafer as described previously, ${ }^{23,34,35}$ with connective wires between contact pads on the edges of the chips and working electrodes in the center were covered but the contact pads and working electrodes left exposed. This ensured a fixed working electrode surface area of $2 \mathrm{~mm}^{2}$. SU- 8 photoresist was cured $\left(150{ }^{\circ} \mathrm{C}, 15 \mathrm{~min}\right)$ and wafers cleaved into individual chips using a Dynatex Scriber/Breaker or broken manually after scoring with a diamond tip scriber.

\section{DNA-Modified Electrode Assembly/Preparation.}

Multiplexed chips were cleaned using sonication in acetone and isopropyl alcohol as described previously. ${ }^{34}$ Chips were then dried thoroughly using argon gas and ozone-cleaned for $20 \mathrm{~min}$ at $20 \mathrm{~mW}$ using a Uvo brand ozone cleaner. Clean chips were assembled onto polycarbonate holders with acrylic clamp and Buna-N rubber gasket according to previous protocols, with four quadrants in the chip separated by fastened gasket and clamp. ${ }^{34}$ Duplex DNA substrates, with a thiol modifier at the $5^{\prime}$ end, $(25 \mu \mathrm{M})$ were deposited in a $20 \mu \mathrm{L}$ volume onto each quadrant of the multiplex chip. Substrates incubated for 18-24 h on the gold surface to allow formation of self-assembled DNA monolayer. DNA monolayers were washed with phosphate buffer (5 $\mathrm{mM}$ phosphate, $\mathrm{pH} 7.0,50 \mathrm{mM} \mathrm{NaCl}, 5 \%$ glycerol) and subsequently backfilled with $1 \mathrm{mM}$ 6-mercaptohexanol (Sigma) in phosphate buffer for 45 $\min$. Monolayers are then washed 10 times per quadrant with phosphate buffer and twice per quadrant with TBP buffer ( $5 \mathrm{mM}$ phosphate, $\mathrm{pH} 7.0,50 \mathrm{mM} \mathrm{NaCl}, 4 \mathrm{mM} \mathrm{MgCl} 2,4 \mathrm{mM}$ spermidine) to aid in formation of a monolayer with termini accessible for $\mathrm{p} 58 \mathrm{C}$ binding. Assembled chips were transported into an anaerobic glovebag chamber (Coy Products) and washed 5 times per quadrant with p58C buffer (20 mM HEPES, pH 7.2, $75 \mathrm{mM} \mathrm{NaCl}$ ), which was previously deoxygenated by argon bubbling (at least $1 \mathrm{~s} / \mu \mathrm{L}$ of solution) and allowed to incubate at least 1-2 days in the chamber prior to the experiment.

Initial cyclic voltammetry scans of the monolayers in p58C buffer were performed to ensure monolayer formation on each electrode. All washes were performed with $20 \mu \mathrm{L}$ buffer volumes on each quadrant. Before scanning, a $200 \mu \mathrm{L}$ volume was deposited over the chip surface, a bulk solution well for completion of a three-electrode circuit with an external reference and counter electrode.

\section{Sample Preparation for Electrochemistry.}

Samples were stored prior to experiments in p48/p58 storage buffer ( $20 \mathrm{mM}$ Tris, $\mathrm{pH} 7.2$, $150 \mathrm{mM} \mathrm{NaCl}$, 5\% glycerol). All p48/p58 samples were transferred to HEPES electrochemistry buffer (20 mM HEPES, pH 7.2, $150 \mathrm{mM} \mathrm{NaCl}, 5 \%$ glycerol) using Amicon ultra centrifugal filters ( $0.5 \mathrm{~mL}, 3 \mathrm{kDa}$ MWCO) (Millipore Sigma). Catalytic metals were not included in the electrochemistry buffer so as to prevent NTP polymerization during electrochemistry experiments. Protein was applied in a $90-140 \mu \mathrm{L}$ volume to the filter and 
centrifuged for $15 \mathrm{~min}$ at $14000 \mathrm{~g}$ at $4{ }^{\circ} \mathrm{C}$. After centrifugation, $400 \mu \mathrm{L}$ of HEPES electrochemistry buffer was applied to the filter and centrifuged at $14000 \mathrm{~g}$ for $20 \mathrm{~min}$. This procedure was repeated four times to exchange the $\mathrm{p} 48 / \mathrm{p} 58$ protein into HEPES electrochemistry buffer. After buffer exchange and recovery of sample by centrifugation ( 2 min, $1000 \mathrm{~g}$ ), the concentration of [4Fe $4 \mathrm{~S}$ ] cluster-containing protein and loading of the [4Fe4S] cluster were assessed using UV-visible spectroscopy, by absorbance of the [4Fe4S] cluster at $410 \mathrm{~nm}$ (extinction coefficient $=17000 \mathrm{M}^{-1} \mathrm{~cm}^{-1}$ ) (see Figure S2). ${ }^{36}$ Recovered samples (approximately 100-150 $\mu \mathrm{L}$ volume) were deoxygenated for 2-3 min with argon. Samples were then transferred into the anaerobic chamber (Coy Laboratory products). Before deposition onto the gold electrode surface, p48/p58 samples were diluted to a molar concentration of $5 \mu \mathrm{M}$ or $7.5 \mu \mathrm{M}$ [4Fe4S] p48/p58 with previously deoxygenated HEPES electrochemistry buffer. Samples were deposited onto multiplex chip quadrants in $20 \mu \mathrm{L}$ volumes initially, with the remaining sample deposited in a well of bulk solution above the chip surface, to a final volume of $200-300 \mu \mathrm{L}$.

\section{Wild Type Human p48/p58 Electrochemistry.}

All electro-chemistry was performed using a CHI620D potentiostat and 16-channel multiplexer (CH Instruments), in an anaerobic glove chamber. Multiplex gold electrodes were part of a three-electrode system with an external $\mathrm{Ag} / \mathrm{AgCl}$ reference electrode (Bioanalytical Systems) and platinum counter electrode. Cyclic voltammetry scans were performed at $100 \mathrm{mV} / \mathrm{s}$ scan rates, over a potential range of +0.412 to $-0.288 \mathrm{~V}$ vs NHE or +512 to $-188 \mathrm{mV}$ vs NHE. Bulk electrolysis on DNA was performed at an applied potential of $+0.512 \mathrm{~V}$ vs NHE for all electrochemical oxidation reactions and $-0.188 \mathrm{~V}$ vs NHE for all electrochemical reduction reactions. The oxidizing potential was applied for at least 8.33 min for single oxidation reactions on a surface. The reducing potential was applied for 8.33 min in all electrochemical reduction reactions. All bulk electrolysis and cyclic voltammetry was performed in previously deoxygenated p48/p58 storage buffer (20 mM HEPES, pH 7.2, $150 \mathrm{mM} \mathrm{NaCl}, 5 \%$ glycerol). Charge transfer (nC) in the cathodic peak of CV scans for oxidized samples was assessed using the area under the current wave of the reduction signal. Charge transfer was measured for oxidized samples using CHI software, assessing the area under the reductive peak in $\mathrm{CV}$ after electrochemical oxidation. Yields for bulk electrolysis were assessed by subtracting the total charge reported in coulombs from the product of the electrolysis time (s) and the final current value (A). NTP-dependence of electrochemical signals were measured by pipetting a small volume (1-3 $\mu \mathrm{L})$ of 0.1 M ATP stock solution into each quadrant of the multiplexed chip setup.

Samples were added by quadrant, as physical barriers in the setup prevent diffusion of NTPs between electrode quadrants. After the volume of ATP stock was deposited onto the electrode quadrant, resulting in a $3.3 \mathrm{mM}$ concentration of ATP in the quadrant, CV scans were measured (100 mV/s scan rate). Charge transfer was assessed using CHI software; charge values were determined by calculation of the area under the reductive and oxidative peak curves. Midpoint potentials of NTP-dependent redox signals were assessed using the peak selection function in CHI software. 


\section{Primase Preincubation Initiation Assays.}

All primase assays were performed anaerobically, with deoxygenated buffers and reagents. Primase was preincubated at ambient temperature, either in a stock alone, with the DNA, or with the NTPs used in the reaction. The preincubation conditions were $30 \mathrm{~min}$ at ambient temperature; only DNA or NTPs, not both substrates at once, were incubated with each sample of primase. The $a{ }^{32} \mathrm{P}$ ATP was initially dried $(2.5 \mu \mathrm{L}$ of $12 \mu \mathrm{M}$, eventually diluted to $30 \mu \mathrm{L}$ ) in vacuo overnight the day preceding the reactions. The ${ }^{32} \mathrm{P}$ ATP-containing tubes were then brought into the anaerobic glovebag chamber, along with concentrated stocks of the unlabeled NTPs, CTP and UTP, and the single-stranded 50-nt initiation substrate, shown in Table S1. Preincubation mixtures consisted of the following: protein-only preincubation samples contained $800 \mathrm{nM} \mathrm{p} 48 / \mathrm{p} 58$ in primase activity buffer (50 mM Tris, $\mathrm{pH}$ 8.0, $5 \mathrm{mM}$ $\mathrm{MgCl}_{2}$ ), paired with a sample of $500 \mathrm{nM}$ ssDNA and $376 \mu \mathrm{M} \mathrm{UTP}, 224 \mu \mathrm{M} \mathrm{CTP}$, and $2 \mu \mathrm{M}$ $a-{ }^{32} \mathrm{P}$ ATP in activity buffer; DNA/protein preincubation samples contained $800 \mathrm{nM}$ p48/p58 and $500 \mathrm{nM}$ ssDNA and were paired with a sample containing $376 \mu \mathrm{M}$ UTP, 224 $\mu \mathrm{M}$ CTP, and $2 \mu \mathrm{M} a-{ }^{32} \mathrm{P}$ ATP in primase activity buffer; NTP and protein preincubation tubes consisted of a sample containing $800 \mathrm{nM}$ p48/p58 with $376 \mu \mathrm{M}$ UTP, $224 \mu \mathrm{M}$ CTP, and $2 \mu \mathrm{M} a-{ }^{32} \mathrm{P}$ ATP and paired with a sample containing $500 \mathrm{nM}$ ssDNA, all in the Tris activity buffer. These samples were all incubated anaerobically for $30 \mathrm{~min}$ at ambient temperature. The volume of reagents in each of the initial two tubes was $15 \mu \mathrm{L}$ for each reaction, making a total reaction of $30 \mu \mathrm{L}$ when combined and incubated at $37{ }^{\circ} \mathrm{C}$. The final reaction conditions were $400 \mathrm{nM}$ [4Fe4S] p48/p58, $112 \mu \mathrm{M} \mathrm{CTP}, 188 \mu \mathrm{M}$ UTP, $1 \mu \mathrm{M} a-{ }^{32} \mathrm{P}$ ATP, $250 \mathrm{nM}$ ssDNA in $50 \mathrm{mM}$ Tris, $\mathrm{pH} 8.0,5 \mathrm{mM} \mathrm{MgCl}_{2}$. The primase reactions were incubated for $1,3,5,10$, and $30 \mathrm{~min}$ at $37{ }^{\circ} \mathrm{C}$ in anaerobic conditions, and then quenched by an equal volume per $5.5 \mu \mathrm{L}$ reaction aliquot of $1 \%$ SDS, $25 \mathrm{mM}$ EDTA quenching solution to stop the reaction. Reactions, when quenched, were then transported out of the anaerobic chamber and heat-denatured for $10 \mathrm{~min}$ at $70{ }^{\circ} \mathrm{C}$, aerobically. Finally, to remove the excess free ${ }^{32} \mathrm{P}$-labeled nucleotide, the samples were each passed through spin columns (Mini Quick Spin Oligo Columns, Roche) according to manufacturer's protocols, to separate unincorporated radioactivity from small products made during primase initiation (7-10 nt). Samples were then scintillation-counted and dried overnight in vacuo. The samples were then separated using $20 \%$ polyacrylamide gel electrophoresis (denaturing gel). Gels were warmed at 1700-2000 V (90 W) for approximately $1.5 \mathrm{~h}$ before loading samples. Samples were resuspended after drying in $2 \mu \mathrm{L}$ of formamide loading dye, vortexed, centrifuged, and heated at $90{ }^{\circ} \mathrm{C}$ for $1 \mathrm{~min}$. They were then loaded onto the gel and run at $\sim 2000 \mathrm{~V}(90 \mathrm{~W})$ for $3.5 \mathrm{~h}$. Gels were then exposed to a phosphor screen (GE Healthcare) for $14 \mathrm{~h}$ and imaged on a Typhoon 9000 Phosphorimager (GE Healthcare). Products were quantified using ImageQuant TL software; reported numbers are mean \pm SD values for $n=3$ trials.

\section{Preincubation Reactions: Elongation.}

For primase elongation reactions, preincubation, reaction, and purification conditions were generally similar to those of initiation assays. Reagents were prepared in essentially the same manner as for initiation. $2.5 \mu \mathrm{L}$ of $12 \mu \mathrm{M} a-{ }^{32} \mathrm{P}$ ATP was dried in vacuo overnight for each elongation reaction, then transported into the anaerobic chamber. Preincubation mixtures were prepared similarly to those used in initiation assays; two $15 \mu \mathrm{L}$ fractions of reagents in various combinations were prepared for each reaction and allowed to incubate in 
the anaerobic chamber for $30 \mathrm{~min}$ at ambient temperature before being mixed and reacted at $37^{\circ} \mathrm{C}$. The primase only preincubation samples consisted of $800 \mathrm{nM} \mathrm{p} 48 / \mathrm{p} 58$ and a paired sample of $1 \mu \mathrm{M}$ dsRNA/DNA and $360 \mu \mathrm{M}$ UTP, $240 \mu \mathrm{M} \mathrm{CTP}$, and $2 \mu \mathrm{M} a-{ }^{32} \mathrm{P}$ ATP all in primase activity buffer; DNA/protein preincubation samples consisted of $800 \mathrm{nM} \mathrm{p} 48 / \mathrm{p} 58$ and $1 \mu \mathrm{M}$ dsRNA/DNA and a paired sample of $360 \mu \mathrm{M}$ UTP, $240 \mu \mathrm{M}$ CTP, and $2 \mu \mathrm{M} a-{ }^{32} \mathrm{P}$ ATP all in primase activity buffer; NTP/primase preincubation samples contained $800 \mathrm{nM}$ p48/p58 with $360 \mu \mathrm{M}$ UTP, $240 \mu \mathrm{M}$ CTP, and $2 \mu \mathrm{M} a-{ }^{32} \mathrm{P}$ ATP and a paired sample of 1 $\mu \mathrm{M}$ dsRNA/DNA, all in primase activity buffer. The final reaction conditions, consequently, were $400 \mathrm{nM}$ p48/p58, $120 \mu \mathrm{M}$ CTP, $180 \mu \mathrm{M}$ UTP, $1 \mu \mathrm{M} a-{ }^{32} \mathrm{P}$ ATP and $500 \mathrm{nM} 2^{\prime}$-OMe RNA-primed DNA in $50 \mathrm{mM}$ Tris, $\mathrm{pH} 8.0,5 \mathrm{mM} \mathrm{MgCl}_{2}$. After preincubation and mixing for reaction, each primase assay was incubated anaerobically at $37{ }^{\circ} \mathrm{C}$ and aliquots of the reaction chemically quenched at $1,3,5,10$, and 30 min of reaction time. The chemical quencher for each $5.5 \mu \mathrm{L}$ aliquot of reaction was an equal volume of $1 \%$ SDS, $25 \mathrm{mM}$ EDTA, administered anaerobically. Reactions were further aerobically heat-denatured at $70{ }^{\circ} \mathrm{C}$ for $10 \mathrm{~min}$. Elongation reactions were purified initially using Mini Quick Spin Oligo Columns (Roche) and then using $P \overline{6}$ Micro Bio Spin Columns (BioRad). The Roche columns retain all synthesized products; the initiation products 7-10 nt on the ssDNA segment of the substrate oligonucleotide are purified and quantified with elongation products. The BioRad spin columns have an exclusion limit of $6 \mathrm{kDa}$, or approximately 20 bases, thus eliminating short initiation products from the quantified/purified mixture; this separation allows for comparison of truncated (30-35 nt) products and elongated products $(60 \mathrm{nt})$ in the elongation assays.

\section{RESULTS}

\section{Human DNA Primase Redox Activity on DNA.}

We first sought to investigate whether human primase participates in redox signaling when bound to DNA. Using multiplexed DNA-modified electrodes, we electrochemically monitored the redox activity of WT human DNA primase (p48/p58) using cyclic voltammetry (CV) (Figure 1, Figure 2). Using a 36-mer duplex DNA substrate with a 9-nt, $5^{\prime}$-ssDNA overhang (Table S1) to accommodate the DNA footprint of primase, ${ }^{37}$ we initially observed that electrochemically unaltered WT primase, which is largely in the $[4 \mathrm{Fe} 4 \mathrm{~S}]^{2+}$ redox state, ${ }^{20}$ does not participate in DNA-mediated redox signaling (Figure 2, $\mathrm{S} 1)$. This behavior is similar to electrochemically unaltered human and yeast $\mathrm{p} 58 \mathrm{C}^{20,27}$ on DNA, confirming that the isolated, $[4 \mathrm{Fe} 4 \mathrm{~S}]^{2+}$ primase enzyme is redox-inert. When we scan the unaltered primase enzyme using square wave voltammetry (SWV), a more sensitive electrochemical technique that minimizes background current, however, an irreversible cathodic peak at $-64 \pm 7 \mathrm{mV}$ vs NHE is observed. Oxidation of [4Fe $4 \mathrm{~S}$ ] proteins, like primase, from the resting $[4 \mathrm{Fe} 4 \mathrm{~S}]^{2+}$ state to the $[4 \mathrm{Fe} 4 \mathrm{~S}]^{3+}$ state can lead to further oxidation with degradation of the oxidized cluster to the $[3 \mathrm{Fe} 4 \mathrm{~S}]^{+}$degradation product. ${ }^{24}$ We have, moreover, observed the $[3 \mathrm{Fe} 4 \mathrm{~S}]^{+}$species on the DNA electrodes for mutants of both yeast p58 ${ }^{27}$ and a human base excision repair enzyme MUTYH. ${ }^{38}$ The samples of $\mathrm{p} 48 / \mathrm{p} 58$ were exposed to atmospheric oxygen during purification and preparation for electrochemistry, and this peak potential is consistent with values expected for the irreversible $[3 \mathrm{Fe} 4 \mathrm{~S}]^{+/ 0}$ reduction reaction, ${ }^{38}$ so we assign the signal to trace amounts of $[3 \mathrm{Fe} 4 \mathrm{~S}]^{+}$product formed in 
the primase protein sample (Figure 2). While we observe a residual amount of $[3 \mathrm{Fe} 4 \mathrm{~S}]^{+}$ protein from oxidative damage during aerobic protein preparation, we do not assign this to an electrochemically induced effect. In the absence of oxygen, wild-type [4Fe4S] primase, similarly to p58C, DNA polymerase $\delta$, human MUTYH, and Endonuclease III, 19,20,27,28,38 is stable and can be electrochemically cycled within this mild, physiological potential regime repeatedly during cyclic voltammetry.

We next electrochemically oxidized ( $E_{\text {applied }}=512 \mathrm{mV}$ vs NHE) or electrochemically reduced $\left(E_{\text {applied }}=-188 \mathrm{mV}\right.$ vs NHE) a sample of $7.5 \mu \mathrm{M}[4 \mathrm{Fe} 4 \mathrm{~S}]$ DNA primase on an electrode surface using bulk electrolysis. Strict anaerobic conditions ensured full control over the redox state of the protein. ${ }^{39}$ Subsequent cyclic voltammetry (CV) scans over physiological potentials (Figure 2) show a small reductive peak on the order of $\sim 1 \mathrm{nC}$ charge transport near $-90 \mathrm{mV}$ vs NHE in the oxidized sample. This peak essentially disappears after the first scan to negative, reducing potentials. Interestingly, this small redox signal is also observed in electrochemically reduced primase, though it is smaller than the signal in the initial scan of oxidized primase. In contrast, the $\mathrm{CV}$ of the p58C domain indicates a large reductive peak in the oxidized sample, but no measurable redox activity in the reduced sample (Figure 2). Hence, only the primase heterodimer is capable of supporting complete redox cycles. Because the reductive peak in the oxidized primase sample disappears after one scan to reductive potentials and is at a different redox potential, it is not indicative of the cluster degradation product $[3 \mathrm{Fe} 4 \mathrm{~S}]^{+}$and its subsequent reduction to the $[3 \mathrm{Fe} 4 \mathrm{~S}]^{0}$ species. Thus, human primase can participate in redox signaling to some degree in the presence of DNA only, but additional factors are necessary to observe robust redox switching between $[4 \mathrm{Fe} 4 \mathrm{~S}]^{2+}$ and $[4 \mathrm{Fe} 4 \mathrm{~S}]^{3+}$ oxidation states.

\section{DNA-Mediated, NTP-Dependent Redox Signaling in Human Primase.}

The relatively small redox signal for oxidized $[4 \mathrm{Fe} 4 \mathrm{~S}]^{3+}$ primase generated on a DNA electrode (Figure 2), relative to that observed for the isolated p58C domain, indicates that their environments are distinctly different. One important point is that the primase heterodimer binds DNA more tightly than either $\mathrm{p} 48$ or $\mathrm{p} 58 \mathrm{C}$ in both human ${ }^{20,40}$ (Figure 3) and yeast ${ }^{9}$ primase. To verify that this is the case for our preparations, we measured DNA binding of human primase and isolated p58C using fluorescence anisotropy, and found that reduced full-length primase (p48/p58) binds DNA with $K_{\mathrm{d}}=0.30 \pm 0.03 \mu \mathrm{M}$, whereas reduced p58C binds $\sim 20$-fold more weakly with $K_{\mathrm{d}}=5.5 \pm 0.5 \mu \mathrm{M} .^{20}$

We next investigated whether binding of NTPs in addition to DNA would promote redox signaling. An NTP pool present on the electrode surface allows sampling of catalytically relevant configurations by primase, while the absence of catalytic metals prevents polymerization. Divalent $\mathrm{Mg}^{2+}$ ions in millimolar concentrations moreover can coat the DNA on the electrode surface and occlude primase binding and redox signal generation. Upon incubating $5 \mu \mathrm{M} \mathrm{p} 48 / \mathrm{p} 58$ on a DNA electrode with $3.3 \mathrm{mM}$ [ATP+CTP], to promote NTP binding at the ss/dsDNA junction of the substrate conjugated to the Au surface, we observe that primase consistently displays a robust, semireversible redox signal. (Figure 3) The NTP-dependent CV signal for human DNA primase is attenuated in the presence of an abasic site in the DNA duplex $(14 \pm 2 \mathrm{nC}$ charge transfer in the cathodic peak for well- 
matched DNA versus $9 \pm 4 \mathrm{nC}$ charge transfer in the cathodic peak for abasic site-containing DNA), consistent with our previous results showing the signal is DNA-mediated. ${ }^{20}$ (Figure

3) In our HEPES electrochemistry buffer (20 mM HEPES, pH 7.2, $150 \mathrm{mM} \mathrm{NaCl}, 5 \%$ glycerol), the signal is centered near $160 \mathrm{mV}$ vs NHE. This signal is within the range expected for DNA-processing [4Fe4S] enzymes cycling between the [4Fe4S $]^{2+}$ and $[4 \mathrm{Fe} 4 \mathrm{~S}]^{3+}$ states, ${ }^{19,20,24-29}$ and is similar to the reported values for human and yeast p58 $\mathrm{C}^{20,27}$ in the presence of DNA and NTPs.

The midpoint potential of primase in the presence of DNA and NTPs $(160 \pm 4 \mathrm{mV}$ vs NHE) is slightly higher than the midpoint potentials observed for human and yeast $\mathrm{p} 58 \mathrm{C}$ in the presence of DNA and NTPs, which is near $150 \mathrm{mV}$ vs NHE. ${ }^{20,27}$ This shift may be due to an increased amount of insulating protein matrix surrounding full-length primase as compared to $\mathrm{p} 58 \mathrm{C}$, which promotes a higher reduction potential. ${ }^{32}$ Binding of the DNA polyanion and negatively charged NTPs, importantly, still shifts the cluster potential of full-length primase into the physiological range for signaling activity. This result suggests that unlike $\mathrm{p} 58 \mathrm{C}$, the redox switch allows primase to cycle between the $[4 \mathrm{Fe} 4 \mathrm{~S}]^{3+}$ state and the $[4 \mathrm{Fe} 4 \mathrm{~S}]^{2+}$ state, presumably because primase remains associated with both DNA and NTPs. In the enzymatically competent form, primase readily participates in DNA-mediated redox signaling.

The NTP-dependent electrochemical signal observed for $\mathrm{p} 48 / \mathrm{p} 58$ demonstrates that primase can readily undergo a redox switch driven by the [4Fe4S] cluster cofactor upon forming an initiation complex with bound DNA and NTPs. Structural and biochemical evidence $e^{7,40,41}$ suggest that this redox switch is accompanied by a realignment of the subunits within the p48/p58 heterodimer. The X-ray crystal structure of free primase in the absence of substrates shows it adopts an "open" conformation ${ }^{7}$ with the RNA polymerase domain and the p58C domain $\sim 60 \AA$ apart. However, both the $\mathrm{p} 48$ and $\mathrm{p} 58 \mathrm{C}$ domains of DNA primase contribute to binding of the DNA and two NTPs necessary to form the initiation complex. ${ }^{13,40-42}$ The primase heterodimer must therefore undergo a configurational reorientation so that the $\mathrm{p} 58 \mathrm{C}$ domain is positioned over the DNA template and the p48 catalytic site in order for priming to occur. The shift from the open configuration of DNA primase may be critical to both proper alignment of critical domains, NTPs and DNA template, and also the change in the electrostatic environment of the cluster in p58C.

\section{Effects of NTP and DNA on Initiation and Elongation.}

To further assess the effect of DNA template and NTP binding on initiation and elongation activity, we preloaded p48/p58 with either DNA or NTPs under anaerobic conditions, then measured polymerase activity during in vitro primer initiation and elongation. WT p48/p58 was first preincubated with template DNA (ssDNA for initiation, dsRNA/DNA for elongation, Table S1) or NTPs for $30 \mathrm{~min}$ in an anaerobic chamber at ambient temperature. Reactions were then begun by adding the remaining necessary substrates for activity to each sample and incubating the mixtures at $37^{\circ} \mathrm{C}$. All preincubation samples contained the same concentration of primase in the same total volume $(15 \mu \mathrm{L})$. The final initiation reaction conditions were $400 \mathrm{nM}$ [4Fe4S] p48/p58, $112 \mu \mathrm{M}$ CTP, $188 \mu \mathrm{M}$ UTP, $1 \mu \mathrm{M} a-{ }^{32} \mathrm{P}$ ATP, $250 \mathrm{nM}$ ssDNA (initiation substrate in Table S1) in $50 \mathrm{mM}$ Tris, $\mathrm{pH} 8.0,5 \mathrm{mM} \mathrm{MgCl}_{2}$, and 
the final elongation reaction conditions were $320 \mathrm{nM}$ p48/p58, $500 \mathrm{nM}$ primed DNA (elongation substrate in Table S1), $180 \mu \mathrm{M}$ [UTP], $120 \mu \mathrm{M}$ [CTP], $1 \mu \mathrm{M} a{ }^{32} \mathrm{P}$ ATP in 50 $\mathrm{mM}$ Tris, $\mathrm{pH} 8.0,5 \mathrm{mM} \mathrm{MgCl}$. We measured the products synthesized after quenching reaction mixtures at $t=1,3,5,10$, and $30 \mathrm{~min}$.

We observe that preloading of primase with template DNA or NTPs does not enhance de novo primer synthesis on ssDNA (Figure S3, Figure S4). Both total products and primerlength (7-10 nt) products were quantified and normalized to primase-only incubation conditions. Levels of primer synthesis were indistinguishable across all preincubation conditions; loading primase with ssDNA or NTPs before the priming reaction did not confer any advantage. These data contrast, interestingly, with the previously observed effect reported by Sheaff et al., who observed no activity when DNA primase is incubated aerobically on a poly(dT) substrate with ATP. ${ }^{12}$ We suspect that the presence of atmospheric oxygen may have nonspecifically oxidized ATP-bound p48/p58, thereby inhibiting initiation activity that is promoted by the redox switch. As NTP binding appears electrochemically to promote primase accessing the $[4 \mathrm{Fe} 4 \mathrm{~S}]^{3+}$ redox state, it is expected that NTP-bound primase would be more susceptible to oxidation to the $[4 \mathrm{Fe} 4 \mathrm{SS}]^{3+}$ state, and subsequent degradation to the $[3 \mathrm{Fe} 4 \mathrm{~S}]^{+}$species in aerobic conditions. ${ }^{24,38}$

Primase elongation, in contrast, is aided by preincubation with NTPs or, to a lesser extent, a primed DNA substrate (Figure 4). Incubation with NTPs increases the number of total products synthesized on primed DNA 1.5-3-fold compared to primase not preloaded with substrates.

Incubation with template DNA increases catalytic activity by a modest degree; $t=1 \mathrm{~min}$ showed no difference in products under these conditions, and $t=30 \mathrm{~min}$ showed the largest increase, synthesizing $187 \%$ of the products formed when primase was incubated without any substrates. These numbers increase slightly (Figure 4 ) when only elongation products (32-60 nt) are quantified and compared to primase only preincubation conditions. We also conducted these assays under aerobic conditions and saw the same general pattern with more error, likely due to nonspecific oxidation of the primase cluster over time. ${ }^{39}$

\section{DISCUSSION}

The dynamic interdomain movement and interactions of the heterodimeric DNA primase enzyme (p48/p58) are distinct from the isolated catalytic domain in the p48 subunit and the [4Fe4S] domain in the p58 subunit. Here we show that the [4Fe4S] cluster in p58C participates in DNA-mediated redox signaling in the context of the full p48/p58 heterodimer. Comparison of the electrochemical behavior of the primase dimer versus p58C is highly informative because the $[4 \mathrm{Fe} 4 \mathrm{~S}]$ domain acts in concert with the catalytic p48 subunit to regulate priming. In isolation, the oxidized and reduced p58C domain exhibit very different electrochemical properties. ${ }^{20}$ Remarkably, electrochemically oxidized and reduced p48/p58 behave similarly in the presence of a DNA template.

We attribute this effect to the alignment of $\mathrm{p} 58 \mathrm{C}$ in close proximity to the $\mathrm{p} 48$ subunit, which is promoted by the interaction of both subunits with the polyanionic DNA. ${ }^{42} \mathrm{We}$ 
postulate the alignment of the two domains of the heterodimer may also affect the coupling of the cluster to the DNA bases. Thus, the primase heterodimer readily participates in robust, semireversible electrochemical activity only in the presence of both DNA and NTPs. NTP binding has been demonstrated previously to enhance redox activity of [4Fe4S] enzymes on DNA, as in the case of DNA repair helicase XPD. The [4Fe4S] cluster in XPD, an ATPdependent enzyme, is better coupled into the DNA bases in the presence of ATP and thus may signal other [4Fe4S] repair enzymes on DNA when it is active. ${ }^{44}$ The concurrent switches to enhanced redox signaling and enzymatic activity may indicate a general linkage between catalytic and regulatory functions of DNA-processing, [4Fe4S] enzymes. We also observe that preloading of primase with NTPs or primed DNA enhances catalytic activity. The p48/p58 complex may sample more configurations that promote primer synthesis when loaded with one of the required substrates for catalysis, resulting in more complete and efficient elongation.

It is reasonable to conclude that electrostatic interactions with the primase [4Fe4S] cluster drive the substrate-dependent change in primase redox behavior. These clusters are tunable cofactors, with redox potentials influenced by factors such as solvent exposure and electrostatic environment. ${ }^{32}$ DNA and NTPs both carry multiple negative charges, and binding to DNA has previously been demonstrated to alter redox properties of [4Fe4S] DNA repair proteins such as base excision repair glycoslyases MutY and Endonuclease III in Escherichia coli. ${ }^{28,43}$ Binding of DNA shifts the redox potential of the cluster negative, stabilizing the oxidized $[4 \mathrm{Fe} 4 \mathrm{~S}]^{3+}$ protein.

Electrochemically oxidized $[4 \mathrm{Fe} 4 \mathrm{~S}]^{3+}$ Endonuclease III was moreover directly demonstrated to bind 500-fold more tightly to DNA than reduced [4Fe4S $]^{2+}$ Endonuclease III using microscale thermophoresis. ${ }^{28}$ Upon modeling the addition of negative charges from DNA into the Endonuclease III cluster environment, the change in potential could be calculated by summing the electrostatic interactions between negative charges on bound DNA and the positively charged [4Fe4S] cofactor. This model predicted the potential shifts of both MutY and Endonuclease III upon DNA binding, and it is interesting to think about expanding the model to consider DNA-binding, NTP-binding [4Fe4S] enzymes like primase. The electrostatic maps of the isolated p48 subunit, and the DNA-bound p58C subunit (Figure S5) illustrate the two electrostatic surfaces we predict are aligned during substrate binding and primase activity. We predict from these structures that the p58C [4Fe4S] cluster is approximately 25-30 ̊ from the bound DNA substrate during primer synthesis. The lack of structural data on NTP-bound primase/p58C poses a challenge for predicting the distance between the $[4 \mathrm{Fe} 4 \mathrm{~S}]$ cluster and bound NTPs during activity, but based on the changes in primase electrochemistry upon NTP binding, as well as the observed electrostatic effects on the $[4 \mathrm{Fe} 4 \mathrm{~S}]$ cluster potentials of MutY and EndoIII, ${ }^{29,43}$ we propose that NTPs are also within at least $20-30 \AA$ of the cluster, possibly as close as $10 \AA$ from the cofactor. As structural data become available on substrate-bound DNA polymerases, this electrostatic model for predicting potential shifts will become a useful tool for predicting and analyzing the properties of substrate-bound replication proteins that contain [4Fe4S] clusters.

Structures of substrate-bound primase will moreover elucidate important details of the configurational realignment for $\mathrm{p} 48 / \mathrm{p} 58$ to initiate and extend the initial RNA primer. Our 
results show that primase elongation on RNA-primed template DNA is enhanced by preloading NTPs onto the $\mathrm{p} 48 / \mathrm{p} 58$ heterodimer. This result illuminates an important effect, connected with the observed configurational realignment of the primase heterodimer during replication. $6,41,42$

\section{CONCLUSIONS}

Redox switching driven by a change in $[4 \mathrm{Fe} 4 \mathrm{~S}]$ oxidation state has now been demonstrated to modulate the DNA binding affinity of several DNA-processing [4Fe4S] enzymes in a manner that regulates activity. ${ }^{19,20,25,26,43,44}$ The primase heterodimer is regulated by a redox switch in the $[4 \mathrm{Fe} 4 \mathrm{~S}]$ cluster; upon NTP binding the primase cluster can cycle readily between the $[4 \mathrm{Fe} 4 \mathrm{~S}]^{2+}$ and $[4 \mathrm{Fe} 4 \mathrm{~S}]^{3+}$ oxidation states, the p58C domain binding more tightly once oxidized. The electrostatic interaction of polyanionic DNA and NTPs with the primase cluster, in concert with the configurational alignment required for catalytic activity, may allow for efficient and regulated primer synthesis and handoff to DNA polymer-ase $a$ (Figure 5). Structural analysis and modeling performed on polymerase $a$ has suggested that this enzyme also undergoes significant configurational rearrangements during priming. ${ }^{11,45}$ The lagging strand polymerase, DNA polymerase $\delta$, which contains a redox-active [4Fe4S] cluster ${ }^{16,19}$ also adopts different configurations bound to and dissociated from DNA, which are related to polymerase $\delta$ interactions with the proliferating cell nuclear antigen (PCNA) processivity clamp ${ }^{46}$ and here too activity is regulated by the oxidation state of the [4Fe $4 \mathrm{~S}$ ] cluster.

The [4Fe4S] enzymes central to DNA replication often contain many subunits and domains with flexible tethers, which interact with one another over the trajectory of a step such as priming and require careful coordination. Replication polymerases known to contain [4Fe4S] clusters ${ }^{14-16}$ bind DNA, NTPs and dNTPs, anionic substrates that alter the electrostatic environment of the cluster. Both the charged substrates bound to the [4Fe4S] enzyme and the configuration of the polymerase subunits during the reactions are crucial elements determining when and how the proteins participate in redox signaling on DNA. Understanding configurational realignment of subunits and domains, as well as the redox properties of isolated [ $4 \mathrm{Fe} 4 \mathrm{~S}$ ] domains versus the corresponding intact proteins, will facilitate more accurate and thorough construction of [4Fe4S] protein redox signaling networks in replication, and other pathways containing dynamic, multi-subunit [4Fe4S] enzymes.

\section{Supplementary Material}

Refer to Web version on PubMed Central for supplementary material.

\section{ACKNOWLEDGMENTS}

This research was supported by National Institutes of Health grants R01 GM126904 (J.K.B.), R35 GM118089 (W.J.C.), T32 GM80320 (L.E.S. and M.E.H.) and T32GM07616 (E.O.B.) with additional support from the Moore Foundation (J.K.B.) and a Ralph M. Parsons fellowship (E.O.B.). 


\section{REFERENCES}

(1). Moran U; Phillips R; Milo R SnapShot: Key Numbers in Biology. Cell 2010, 141, 1262. [PubMed: 20603006]

(2). O’Donnell ME; Langston L; Stillman B Principles and concepts of DNA replication in bacteria, archaea, and eukarya. Cold Spring Harbor Perspect. Biol 2013, 5, a010108.

(3). Burgers PMJ; Kunkel TA Eukaryotic DNA Replication Fork. Annu. Rev. Biochem 2017, 86, 417. [PubMed: 28301743]

(4). Frick DN; Richardson CC DNA Primases. Annu. Rev. Biochem 2001, 70, 39. [PubMed: 11395402]

(5). Kuchta RD; Stengel G Mechanism and evolution of DNA primases. Biochim. Biophys. Acta, Proteins Proteomics 2010, 1804, 1180.

(6). Arezi B; Kuchta RD Eukaryotic DNA primase. Trends Biochem. Sci 2000, 25, 572. [PubMed: 11084371]

(7). Baranovskiy AG; Zhang Y; Suwa Y; Babayeva ND; Gu J; Pavlov YI; Tahirov TH Crystal structure of the human primase. J. Biol. Chem 2015, 290, 5635. [PubMed: 25550159]

(8). Vaithiyalingam S; Warren EM; Eichman BF; Chazin WJ Insights into eukaryotic priming from the structure and functional interactions of the $4 \mathrm{Fe}-4 \mathrm{~S}$ cluster domain of human DNA primase. Proc. Natl. Acad. Sci. U. S. A 2010, 107, 13684. [PubMed: 20643958]

(9). Sauguet L; Klinge S; Perera RL; Maman JD; Pellegrini L Shared active site architecture between the large subunit of eukaryotic primase and DNA photolyase. PLoS One 2010, 5, e10083. [PubMed: 20404922]

(10). Kilkenny ML; Longo MA; Perera RL; Pellegrini L Structures of human primase reveal design of nucleotide elongation site and mode of pol a tethering. Proc. Natl. Acad. Sci. U. S. A 2013, 110 , 15961. [PubMed: 24043831]

(11). Nunez-Ramirez R; Klinge S; Sauguet L; Melero R; Recuero-Checa MA; Kilkenny M; Perera RL; Garcia Alvarez B; Hall RJ; Nogales E; Pellegrini L; Llorca O Flexible tethering of primase and DNA Pol $a$ in the eukaryotic primosome. Nucleic Acids Res. 2011, 39, 8187. [PubMed: 21715379]

(12). Sheaff RJ; Kuchta RD Mechaniam of Calf Thymus DNA Primase: Slow Initiation, Rapid Polymerization, and Intelligent Termination. Biochemistry 1993, 32, 3027. [PubMed: 7681326]

(13). Copeland WC; Wang TS-F Enzymatic Characterization of the Individual Mammalian Primase Subunits Reveals a Biphasic Mechanism for Initiation of DNA Replication. J. Biol. Chem 1993, 268, 26179. [PubMed: 8253737]

(14). Weiner BE; Huang H; Dattilo BM; Nilges MJ; Fanning E; Chazin WJ An iron-sulfur cluster in the c-terminal domain of the p58 subunit of human DNA primase. J. Biol. Chem 2007, 282, 33444. [PubMed: 17893144]

(15). Klinge S; Hirst J; Maman JD; Krude T; Pellegrini L An iron-sulfur domain of the eukaryotic primase is essential for primer synthesis. Nat. Struct. Mol. Biol 2007, 14, 875. [PubMed: 17704817]

(16). Netz DJA; Stith CM; Stümpfig M; Köpf G; Vogel D; Genau HM; Stodola JL; Lill R; Burgers PMJ; Pierik AJ Eukaryotic DNA polymerases require an iron-sulfur cluster for the formation of active complexes. Nat. Chem. Biol 2012, 8, 125.

(17). Rouault TA Mammalian iron-sulphur proteins: novel insights into biogenesis and function. Nat. Rev. Mol. Cell Biol. 2015, 16, 45. [PubMed: 25425402]

(18). Beinert H; Holm RH; Münck E Iron-Sulfur Clusters: Nature's Modular, Multipurpose Structures. Science 1997, 277, 653. [PubMed: 9235882]

(19). Bartels PL; Stodola JL; Burgers PMJ; Barton JK A Redox Role for the [4Fe4S] Cluster of Yeast DNA Polymerase $\delta$. J. Am. Chem. Soc 2017, 139, 18339. [PubMed: 29166001]

(20). O’Brien E; Holt ME; Thompson MK; Salay LE; Ehlinger AC; Chazin WJ; Barton JK The [4Fe4S] cluster of human DNA primase functions as a redox switch using DNA charge transport. Science 2017, 355, eaag1789. [PubMed: 28232525] 
(21). Nunez ME; Hall DB; Barton JK Long-range oxidative damage to DNA: effects of distance and sequence. Chem. Biol. (Oxford, U. K.) 1999, 6, 85.

(22). Kelley SO; Boon EM; Barton JK; Jackson NM; Hill MG Single-base mismatch detection based on charge transduction through DNA. Nucleic Acids Res. 1999, 27, 4830. [PubMed: 10572185]

(23). Slinker JD; Muren NB; Renfrew SE; Barton JK DNA charge transport over $34 \mathrm{~nm}$. Nat. Chem 2011, 3, 228. [PubMed: 21336329]

(24). Boal AK; Yavin E; Lukianova OA; O’Shea VL; David SS; Barton JK DNA-Bound Redox Activity of DNA Repair Glycosylases Containing [4Fe-4S] Clusters. Biochemistry 2005, 44, 8397. [PubMed: 15938629]

(25). Grodick MA; Segal HM; Zwang TJ; Barton JK DNA-Mediated Signaling by Proteins with 4Fe-4S Clusters Is Necessary for Genomic Integrity. J. Am. Chem. Soc 2014, 136, 6470. [PubMed: 24738733]

(26). Boal AK; Genereux JC; Sontz PA; Gralnick JA; Newman DK; Barton JK Redox signaling between DNA repair proteins for efficient lesion detection. Proc. Natl. Acad. Sci. U. S. A 2009, 106, 15237. [PubMed: 19720997]

(27). O’Brien E; Salay LE; Epum EA; Friedman KL; Chazin WJ; Barton JK Yeast Require Redox Switching in DNA Primase. Proc. Natl. Acad. Sci. U.S.A. 2018,

(28). Tse ECM; Zwang TJ; Barton JK The Oxidation State of [4Fe4S] Clusters Modulates the DNABinding Affinity of DNA Repair Proteins. J. Am. Chem. Soc 2017, 139, 12784. [PubMed: 28817778]

(29). Gorodetsky AA; Boal AK; Barton JK Direct electrochemistry of Endonuclease III in the presence and absence of DNA. J. Am. Chem. Soc 2006, 128, 12082. [PubMed: 16967954]

(30). Vaithiyalingam S; Arnett DR; Aggarwal A; Eichman BF; Fanning E; Chazin WJ Insights into eukaryotic primer synthesis from structures of the p48 subunit of human DNA primase. J. Mol. Biol 2014, 426, 558. [PubMed: 24239947]

(31). Zerbe LK; Kuchta RD The p58 subunit of human DNA primase is important for primer initiation, elongation, and counting. Biochemistry 2002, 41, 4891. [PubMed: 11939784]

(32). Dey A; Jenney FA Jr.; Adams MW; Babini E; Takahashi Y; Fukuyama K; Hodgson KO; Hedman B; Solomon EI Solvent tuning of electrochemical potentials in the active sites of HiPIP versus ferredoxin. Science 2007, 318, 1464. [PubMed: 18048692]

(33). Holt ME; Salay LE; Chazin WJ A Polymerase With Potential: The Fe-S Cluster in Human DNA Primase. Methods Enzymol. 2017, 595, 361. [PubMed: 28882207]

(34). Pheeney CG; Arnold AR; Grodick MA; Barton JK Multiplexed electrochemistry of DNA-bound metalloproteins. J. Am. Chem. Soc 2013, 135, 11869. [PubMed: 23899026]

(35). Slinker JD; Muren NB; Gorodetsky AA; Barton JK Multiplexed DNA-modified electrodes. J. Am. Chem. Soc 2010, 132, 2769. [PubMed: 20131780]

(36). Cunningham RP; Asahara H; Bank JF; Scholes CP; Salerno JC; Surerus K; Munck E; McCracken J; Peisach J; Emptage MH Endonuclease III is an iron-sulfur protein. Biochemistry 1989, 28, 4450. [PubMed: 2548577]

(37). Garcia-Diaz M; Bebenek K; Krahn JM; Pedersen LC; Kunkel TA Role of the catalytic metal during polymerization by DNA polymerase lambda. DNA Repair 2007, 6, 1333. [PubMed: 17475573]

(38). McDonnell KJ; Chemler JA; Bartels PL; O’Brien E; Marvin ML; Ortega J; Stern RH; Raskin L; Li G; Sherman DH; Barton JK; Gruber SB A Novel Human MUTYH Variant Causing Colonic Polyposis through Redox Degradation of the $[4 \mathrm{Fe} 4 \mathrm{~S}]^{2+}$ Cluster. Nat. Chem 2018, 10, 873. [PubMed: 29915346]

(39). Imlay JA Iron-sulphur clusters and the problem with oxygen. Mol. Microbiol 2006, 59, 1073. [PubMed: 16430685]

(40). Arezi B; Kirk BW; Copeland WC; Kuchta RD Interactions of DNA with Human DNA Primase Monitored with Photoactivatable Cross-Linking Agents: Implications for the Role of the p58 Subunit. Biochemistry 1999, 38, 12899. [PubMed: 10504261]

(41). Baranovskiy AG; Babayeva ND; Zhang Y; Gu J; Suwa Y; Pavlov YI; Tahirov TH Mechanism of Concerted RNA-DNA Primer Synthesis by the Human Primosome. J. Biol. Chem 2016, 291, 10006. [PubMed: 26975377] 
(42). Kirk BW; Kuchta RD Arg304 of Human DNA Primase Is a Key Contributor to Catalysis and NTP Binding: Primase and the Family X Polymerases Share Significant Sequence Homology. Biochemistry 1999, 38, 7727. [PubMed: 10387012]

43. ) Bartels PL; Zhou A; Arnold AR; Nunez NN; Crespilho FN; David SS; Barton JK

Electrochemistry of the [4Fe4S] Cluster in Base Excision Repair Proteins: Tuning the Redox Potential with DNA. Langmuir 2017, 33, 2523. [PubMed: 28219007]

(44). Mui TP; Fuss JO; Ishida JP; Tainer JA; Barton JK ATP-Stimulated, DNA-Mediated Redox Signaling by XPD, a DNA Repair and Transcription Helicase. J. Am. Chem. Soc 2011, 133, 16378. [PubMed: 21939244]

(45). Perera RL; Torella R; Klinge S; Kilkenny ML; Maman JD; Pellegrini L Mechanism for priming DNA synthesis by yeast DNA polymerase $a$. eLife 2013, 2, e00482. [PubMed: 23599895]

(46). Johansson E; Garg P; Burgers PMJ The Pol32 Subunit of DNA Polymerase Contains Separable Domains for Processive Replication and Proliferating Cell Nuclear Antigen (PCNA) Binding. J. Biol. Chem 2004, 279, 1907. [PubMed: 14594808] 

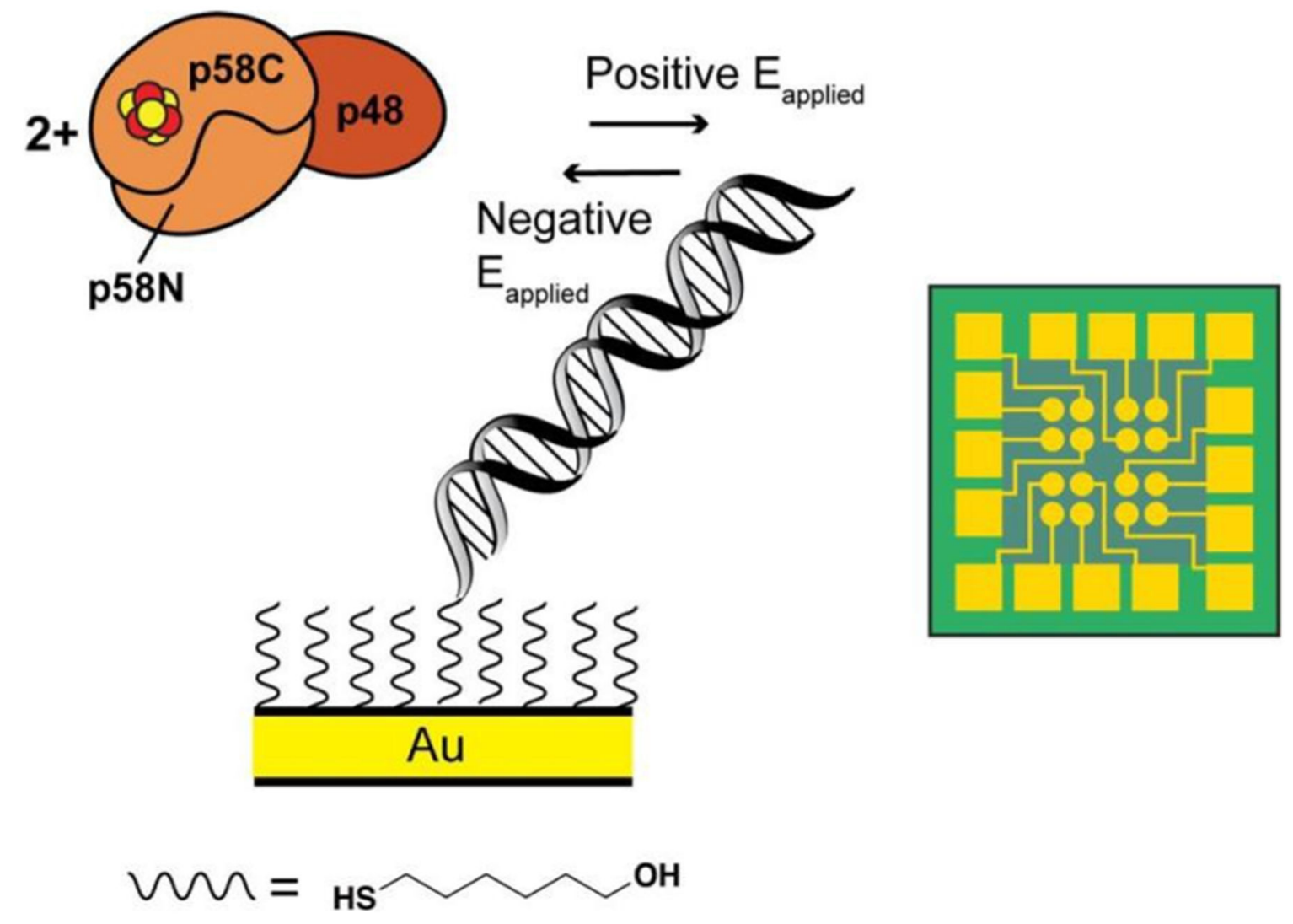

\section{Figure 1.}

Electrochemical oxidation and reduction of human DNA primase. (Left) Scheme for the electrochemistry of p48/p58 in the presence of a DNA substrate. Bulk electrolysis is used to oxidize or reduce the $[4 \mathrm{Fe} 4 \mathrm{~S}]$ cluster in DNA primase, applying positive or negative potentials for oxidation and reduction, respectively. Subsequent cyclic voltammetry scanning, in a strictly anaerobic environment, illuminates the electrochemical behavior of primase in each oxidation state. (Right) Primase electrochemistry is performed on a multiplex DNA electrode platform, with 16 individually addressable electrodes separated into four quadrants on a single surface. The Au electrodes (circles, center) serve as the working electrode in a three-electrode cell, with a $\mathrm{Ag} / \mathrm{AgCl}$ reference and a Pt counter electrode. 


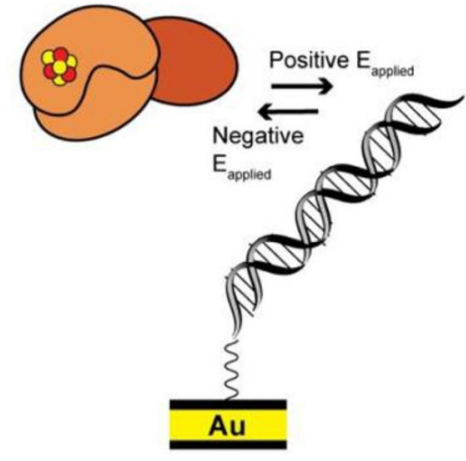

Electrochemically Unaltered p48/p58

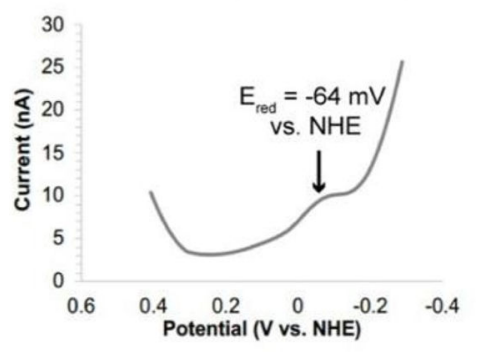

Electrochemically Oxidized p48/p58

$E_{\text {applied }}=512 \mathrm{mV}$ vs. NHE
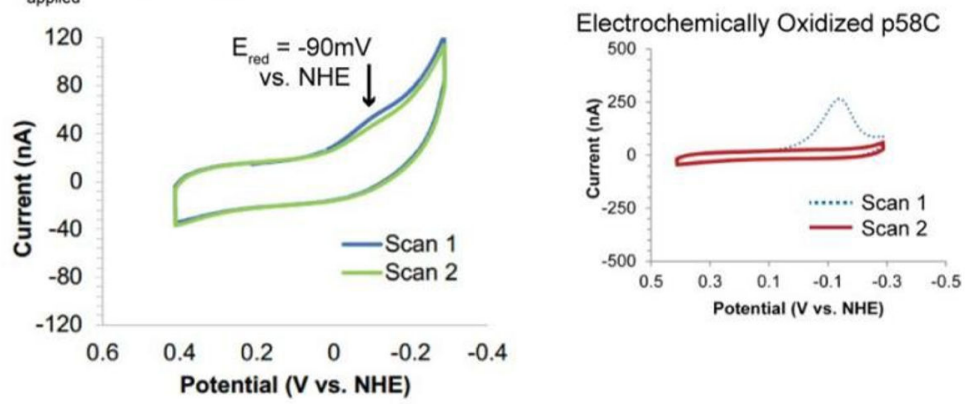

Electrochemically Reduced p48/p58

$E_{\text {applied }}=-188 m V$ vs. NHE

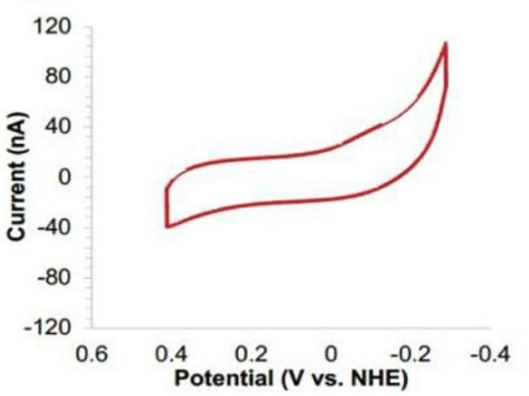

Figure 2.

Electrochemical characterization of human p48/p58 in the presence of DNA. The electrochemically unaltered primase protein contains a small amount of $[3 \mathrm{Fe} 4 \mathrm{~S}]^{+}$cluster degradation product, as observed in the square wave voltammetry (SWV) reductive sweep of the electrochemically unaltered protein (lower left, gray trace). This peak is distinct from the peak observed upon primase electrochemical oxidation at an applied potential of $512 \mathrm{mV} v \mathrm{~s}$ NHE, which is small for the p48/p58 enzyme and disappears after a single scan to reducing potentials. (above center, green and blue traces). The electrochemically reduced sample (below center, red trace) has a similar CV profile. The redox signal for electrochemically oxidized human p58C (inset, right) is much larger, as the isolated domain is not affected by the configuration of the other primase domains, notably the RNA polymerase domain in the p48 subunit. Electrochemical scans were measured in anaerobic conditions, with $7.5 \mu \mathrm{M}$ [4Fe4S] p48/p58 in 20 mM HEPES, pH 7.2, $150 \mathrm{mM} \mathrm{NaCl,} \mathrm{5 \%} \mathrm{glycerol.} \mathrm{CV} \mathrm{scans} \mathrm{were}$ measured at $100 \mathrm{mV} / \mathrm{s}$ scan rate, and SWV scans were measured at $15 \mathrm{~Hz}$ frequency, $25 \mathrm{mV}$ amplitude. 

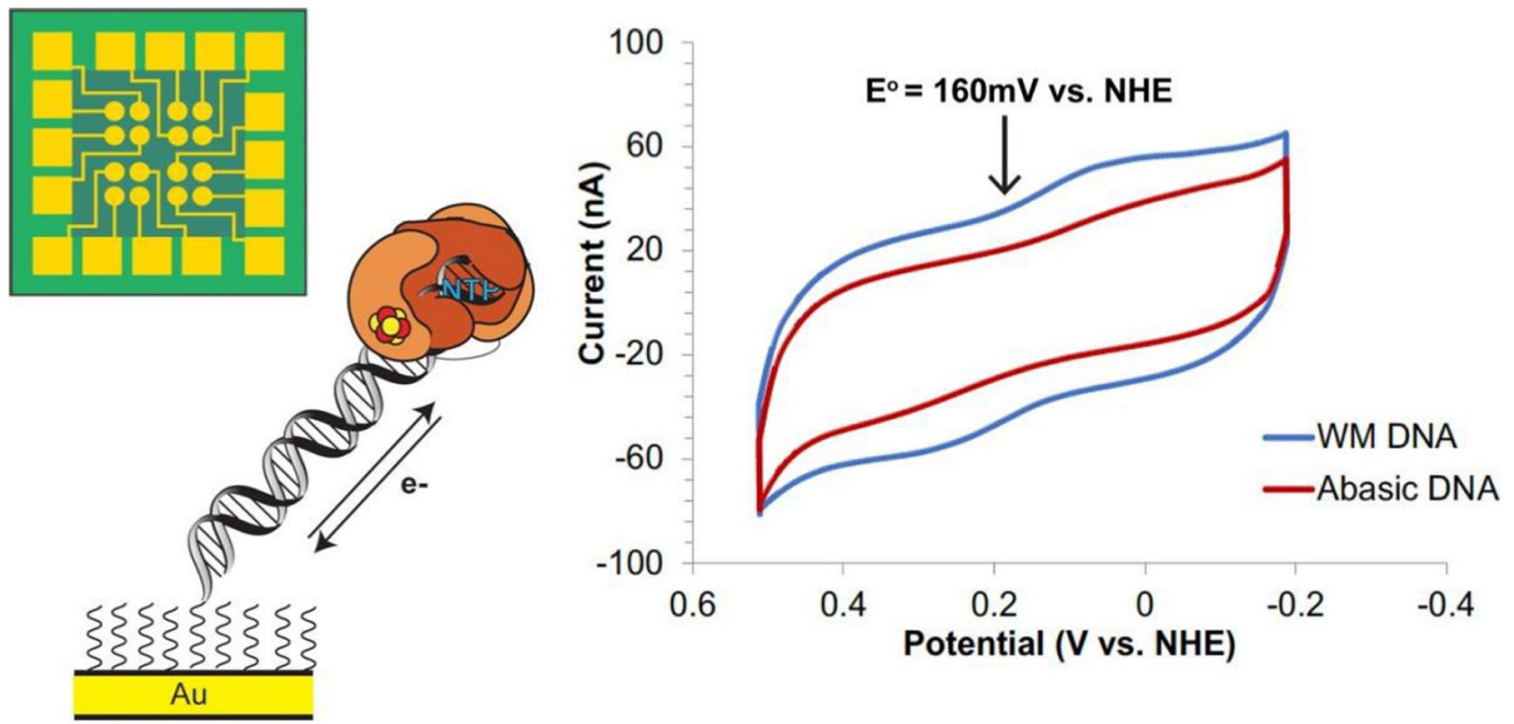

Figure 3.

Semireversible, NTP-dependent redox signaling in $\mathrm{p} 48 / \mathrm{p} 58$. In the absence of NTPs, p48/p58 is redox-inert on DNA. Upon addition of $3.3 \mathrm{mM}$ [ATP+CTP] to the multiplexed DNA electrode surface (right, blue), reversible redox switching between the $[4 \mathrm{Fe} 4 \mathrm{~S}]^{3+}$ and $[4 \mathrm{Fe} 4 \mathrm{~S}]^{2+}$ oxidation states is observed. This signal is centered at $160 \mathrm{mV}$ vs NHE, within the physiological range, as well as the range for signaling with other DNA-processing, [4Fe4S] enzymes. In the presence of a DNA substrate containing an abasic site in the duplex segment of the substrate, the redox signal is attenuated (red), suggesting that the signal is DNA-mediated. This redox chemistry observed in WT p48/p58 suggests that the active form of primase, bound to both DNA and NTPs, is able to participate in redox signaling driven by the $[4 \mathrm{Fe} 4 \mathrm{~S}]$ cluster. Electrochemical scans were measured in anaerobic conditions, with 5 $\mu \mathrm{M}$ [4Fe4S] p48/p58 in $20 \mathrm{mM}$ HEPES, pH 7.2, $150 \mathrm{mM} \mathrm{NaCl}, 5 \%$ glycerol, in the presence of $3.3 \mathrm{mM}$ [ATP+CTP]. CV scans were measured at $100 \mathrm{mV} / \mathrm{s}$ scan rate. 
p48/p58 Only p48/p58 + NTPs p48/p58 + DNA Pre-Incubation Condition

X $13510301351030 \quad 1351030 \quad$ Incubation Time (min, $\left.37^{\circ} \mathrm{C}\right)$
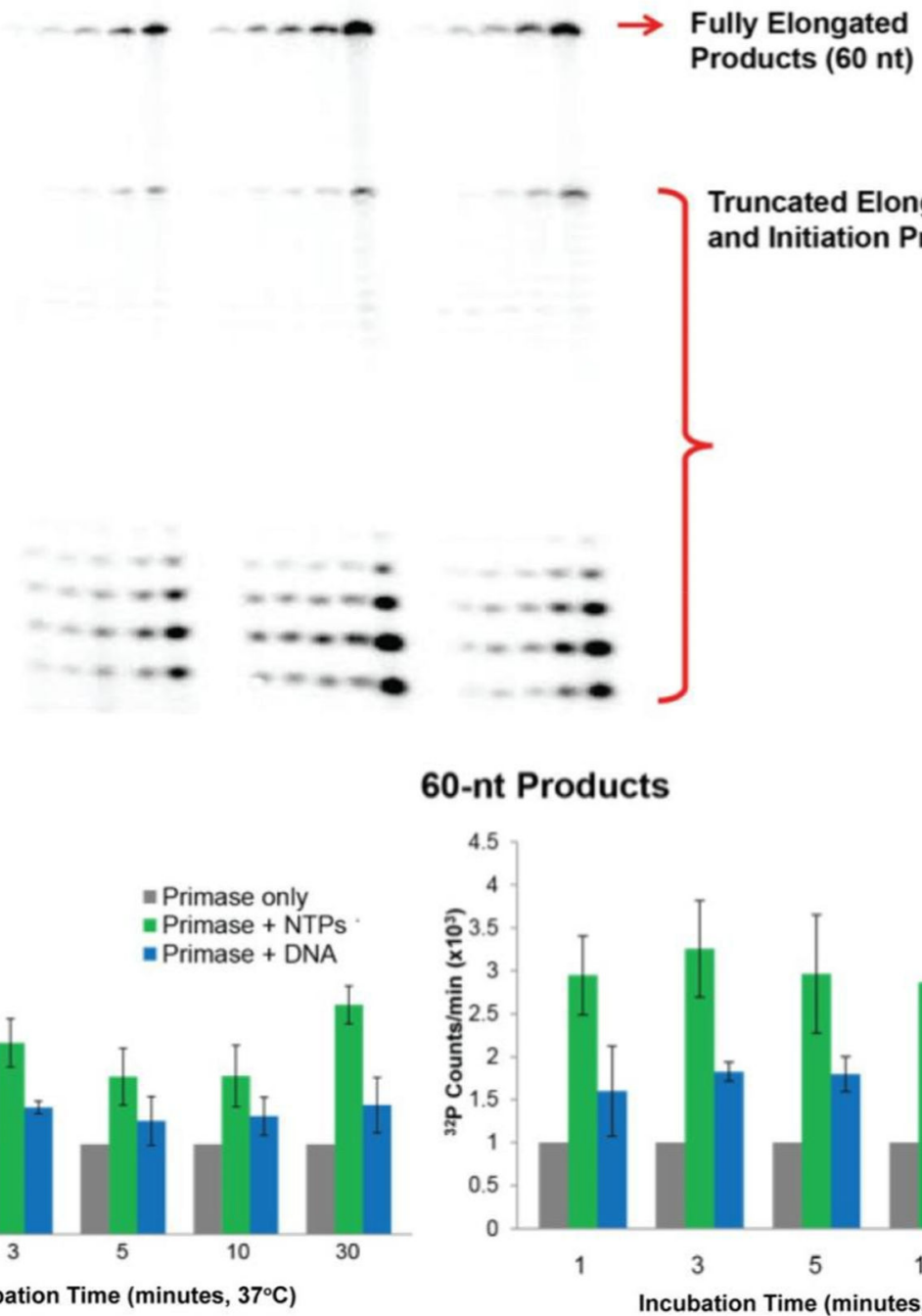

\section{0-nt Products}
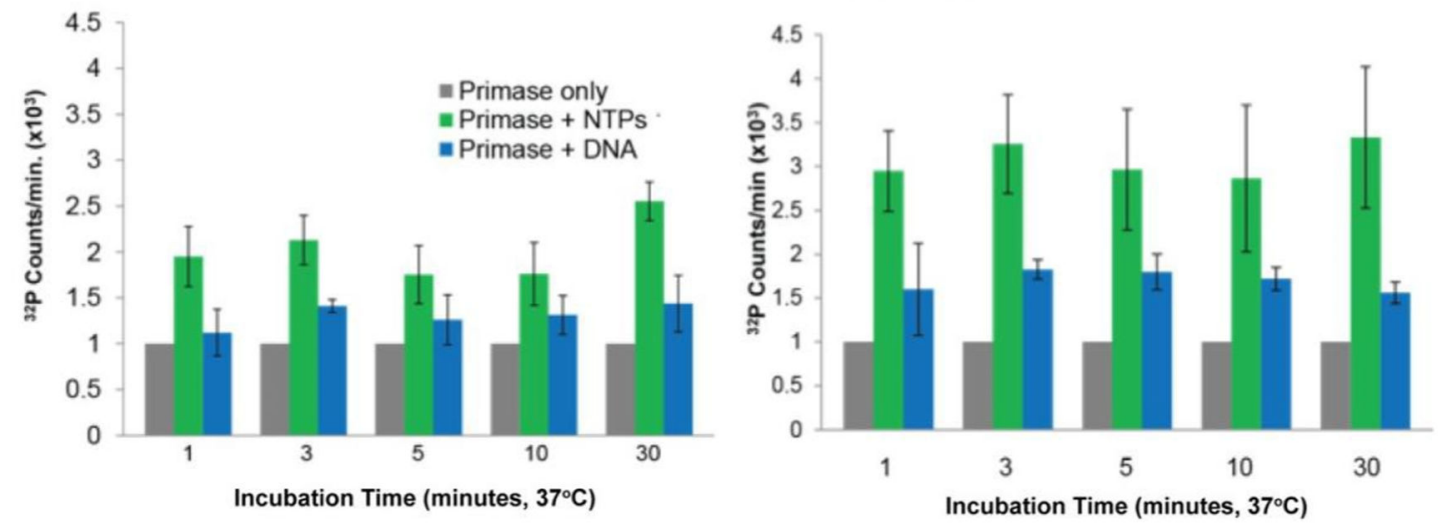

Figure 4.

Primase preloading with DNA and NTPs enhances elongation activity. Primase preincubation with DNA and NTPs increases elongation product synthesis. Catalytic activity, as measured by elongation products, is most enhanced on average by preincubation with NTPs, but preincubation with DNA also enhances product formation. A representative gel for the preincubation conditions is shown above. Quantifications for the total elongation products synthesized (bottom left) and full elongation products (bottom right) are also shown. All experiments were performed under anaerobic conditions, with $320 \mathrm{nM} \mathrm{p} 48 / \mathrm{p} 58$, $500 \mathrm{nM}$ primed DNA, $180 \mu \mathrm{M}$ [UTP], $120 \mu \mathrm{M}$ [CTP], $1 \mu \mathrm{M} a-{ }^{32} \mathrm{P}$ ATP in $50 \mathrm{mM}$ Tris, $\mathrm{pH}$ $8.0,5 \mathrm{mM} \mathrm{MgCl}_{2}$. Quantifications are the mean \pm s.d. of $n=3$ trials. 
DNA only

Incomplete configurational rearrangement, no redox signaling observed

Figure 5.
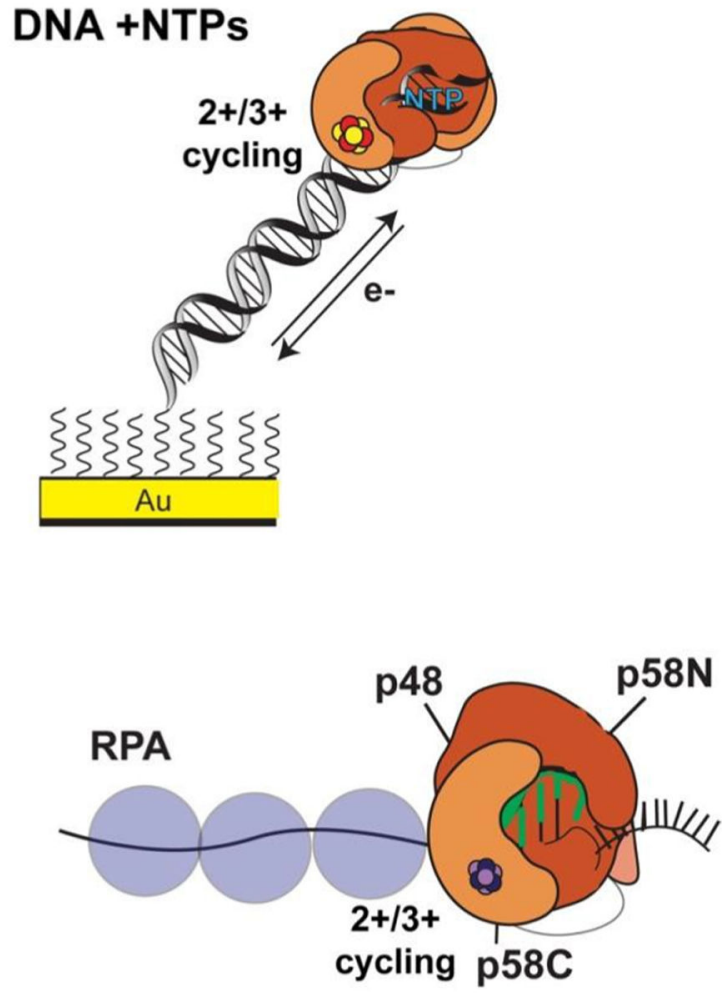

NTP binding completes configurational
rearrangement and changes in cluster
redox properties, [4Fe4S] cluster is
coupled to DNA bases for redox signaling

Model for the effect of substrate binding and configurational realignment on primase redox signaling and activity. When primase is bound only to DNA (top left), the [4Fe4S] cluster domain is not coupled into the DNA bases and only a small amount of redox signaling is observed. When primase is bound to both DNA and NTPs (top right), the protein participates in robust, semireversible redox cycling between the $[4 \mathrm{Fe} 4 \mathrm{~S}]^{2+}$ and $[4 \mathrm{Fe} 4 \mathrm{~S}]^{3+}$ redox states, favoring the tightly bound $[4 \mathrm{Fe} 4 \mathrm{~S}]^{3+}$ state. We propose (below) that the redox switch induced by the electrostatic effect on [4Fe4S] cluster environment, as well as the configurational realignment of primase domains for activity, regulate primer synthesis, which terminates with handoff to polymerase $a$. Binding of polyanionic DNA and NTPs affects the [4Fe4S] cluster reduction potential, enabling the cofactor to participate in redox signaling under physiological conditions. In the heterodimeric primase enzyme, the configurational alignment to form the initiation complex, in which both the p48 and p58C domains contact the nascent primer, additionally contributes to positioning the [4Fe4S] cofactor in an orientation coupled with the DNA bases to perform redox signaling during replication. 